\section{Space-time cluster analysis of American visceral leishmaniasis in Bauru, São Paulo State, Brazil}

\author{
Análise de aglomerados espaço-temporais da \\ leishmaniose visceral americana em Bauru, \\ São Paulo, Brasil
}

\author{
${ }^{1}$ Faculdade de Medicina \\ Veterinária e Zootecnia, \\ Universidade de São Paulo, \\ São Paulo, Brasil. \\ 2 Faculdades Metropolitanas \\ Unidas, São Paulo, Brasil. \\ 3 Seção de Controle de \\ Zoonoses, Secretaria \\ Municipal de Saúde de \\ Bauru, Bauru, Brasil. \\ Correspondence \\ V. A. F. Souza \\ Faculdade de Medicina \\ Veterinária e Zootecnia \\ Universidade de São Paulo. \\ Rua Gal. Bagnuolo 1026, \\ apto. 08, São Paulo, SP \\ 03152-130, Brasil. \\ vanisfeijo@vps.fmvz.usp.br
}

\begin{abstract}
A space-time analysis of American visceral leishmaniasis (AVL) in humans in the city of Bauru, São Paulo State, Brazil was carried out based on 239 cases diagnosed between June 2003 and October 2008. Spatial analysis of the disease showed that cases occurred especially in the city's urban areas. AVL annual incidence rates were calculated, demonstrating that the highest rate occurred in 2006 (19.55/100,000 inhabitants). This finding was confirmed by the time series analysis, which also showed a positive tendency over the period analyzed. The present study allows us to conclude that the disease was clustered in the Southwest side of the city in 2006, suggesting that this area may require special attention with regard to control and prevention measures.
\end{abstract}

Visceral Leishmaniasis; Cluster Analysis; Spatial Analysis
Vanessa Aparecida Feijó de Souza 1,2 Luiz Ricardo Paes de Barros Cortez ${ }^{3}$ Ricardo Augusto Dias 1

Marcos Amaku 1

José Soares Ferreira Neto 1

Rosely Bianca dos Santos Kuroda 1 Fernando Ferreira 1

\section{Introduction}

American visceral leishmaniasis (AVL) is a zoonotic disease caused by protozoan parasites of the genus Leishmania spp. and transmitted by phlebotomine sand flies (World Health Organization. http://www.who.int/leishmaniasis/ en, accessed on 08/Aug/2011) 1. Dogs are considered important reservoir hosts in urban areas as they carry the agent for long periods of time, favoring biologic vector-borne infections and, as a result, maintenance of protozoa 2,3 . In human begins, AVL is described as a serious disease and early diagnosis and treatment are vital to avoid fatalities 4,5 .

In Brazil, AVL affects most parts of the national territory and represents an important public health issue, especially in fast-growing urban areas. Recent data shows that cases reported in this country make up $90 \%$ of all cases registered in Latin America 5. In the State of São Paulo, canine visceral leishmaniasis occurs in 71 cities while the human form is present in 52 urban centers 6 .

Despite the prevention and control measures implemented in the State of São Paulo, human and canine AVL are still spreading ${ }^{6}$. One of the most affected cities is Bauru, where 354 human cases were confirmed between 2003 and 2011 (data collected up to April 2011) 7. Up to date, the space-time pattern of this disease in the City of São Paulo has not been evaluated, emphasizing the need for studies that address this question. 
Epidemiologic surveys are indispensable in AVL control programs since they permit problem analysis by person, time and space, thus enabling researchers to model occurrence and determinate the extent of the disease ${ }^{8}$.

Geographic information systems have been used in epidemiologic studies as a way to improve understanding of health patterns and complement disease prevention and control programs 9,10 . One of its applications is the identification of disease clusters, an important epidemiologic tool that determines unexpected events clustering by space and/or time 11 .

The aims of the current study are to describe disease occurrence in the city of Bauru between 2003 and 2008 and identify space-time disease clusters in order to improve knowledge of this disease in the region.

\section{Material and methods}

\section{Study area}

The study area comprises the city of Bauru which has a total area of $673.49 \mathrm{~km}^{2}$ and is located in the center west of the State of São Paulo (22 $12^{\circ}$ 53 " S, 49 $03^{\prime}$ ' 38” W). Bauru has a population of approximately 343,937 (Brazilian Institute of Geography and Statistics. http://www.censo2010. ibge.gov.br/sinopse/index.php?uf $=35 \&$ dados $=0$, accessed on 08/Aug/2011) and until 2010 the rate of urbanization was $98.5 \%$ (Fundação Seade. http://www.seade.gov.br/produtos/perfil/perfil. php?loc=60, accessed on 08/Aug/2011).

\section{Data}

Data on age, gender and place of residence of AVL patient from June 2003 to October 2008 were supplied by the Bauru City Health Department. Only one of the notified cases for the region during this period occurred in the rural zone and therefore only data for the urban area was used. Diagnostic and treatment measures were used according to the regional AVL surveillance and control program.

The present study was approved by the Ethics Committee of the Faculty of Veterinary Medicine and Zootechny of the University of São Paulo.

\section{Descriptive statistics}

Annual cases and frequencies of human AVL between 2003 and 2008 were calculated and plotted according to gender and age. Data from the Census 2000 was used to draw the age pyramid of Bauru inhabitants. This information was of- ficially published by the Brazilian Institute of Geography and Statistics (IBGE. http://www.ibge. gov.br/home/estatistica/populacao/censo2010/ caracteristicas_da_populacao/default_caracteristicas_da_populacao.shtm, accessed on 23/ Jan/2011).

\section{Incidence rates and time series analysis}

Annual cumulative incidence rates of visceral leishmaniasis were calculated considering the total number of notified cases and the projected population size as at July 1st of each year. The latter information was published by the State System of Data Analysis Foundation (Fundação Seade. http://www.seade.gov.br/produtos/pro jpop/, accessed on 17/Dec/2009).

The disease time series analysis was decomposed utilizing a multiplicative model using the statistic software Minitab v. 15 (Minitab Statistical Software, Minitab Inc., State College, USA). Confirmed case counts were arranged in monthly distributions across the five year period. The method is described as:

$Z(t)=T(t) \times S(t) \times C(t)+I(t)$

Where $Z$ is the time series variable, $T$ is time trends, $S$ is seasonal trends, $C$ is cycle trends and $I$ is irregular trends.

The seasonal indexes were plotted using rainfall data for the city of Bauru. A linear regression analysis was carried out to analyze the correlation between these variables where rainfall was considered as an explanatory variable and seasonal index as a dependent variable $(\alpha=0.05)$.

Meteorological data, consisting of monthly rainfall and temperature between 2003 and 2008, was supplied by the Institute of Meteorological Research of the State University of São Paulo (IPMet. http://web.ipmet.unesp.br/index2. php?menu_esq1=\&abre=ipmet_html/estacao / historico.php, accessed on 17/Dec/2009).

\section{Cluster analysis}

Georeferencing of AVL cases between June 2003 and October 2008 was carried out based on a cartographic street map of the city and the respective addresses of patients. Due to problems with household identification, every case was identified according to the street block centroid. Cases were then associated with their respective census tracts using a digital base containing the political boundaries in 2000. This material is available at the IBGE website (ftp://geoftp.ibge.gov. br/mapas/malhas_digitais/setor_urbano_2000/ SP/3506003, accessed on 20/Oct/2009).

Space-time cluster analysis was performed using the public-domain software SaTScan v. 8.0 
(http://www.satscan.org) based on space-time scan statistics. The test is carried out by gradually scanning a window across time and space, noting the number of expected and observed cases at each location. This window is defined as a cylinder in which the circular or elliptic base corresponds to space and height corresponds to time.

The window size varies between zero and a predefined maximum value related to the percentage of population. Statistics probability is chosen and calculated for each circular (or elliptic) base for each data type. The value is then computed according to observed cases inside and outside the window and compared with $L_{0}$ under the null hypothesis. Circles with a high proportion of cases are considered the most likely clusters and a Monte Carlo simulation is carried out to evaluate the significance level of each detected cluster ${ }^{12}$.

In the current study, the maximum size of the circular window included $50 \%$ of the population at risk. This is the recommended value to avoid bias, since larger windows would indicate exceptionally low rates outside of the circle 12 . The Poisson distribution was calculated using annual occurrence of cases as the temporal unit and a significance level of $5 \%$.

\section{Results}

\section{Descriptive statistics}

A total of 250 autochthonous cases were notified in the city of Bauru urban area between June 2003 and October 2008. Of these cases, 11 were not counted due to inadequate patient data resulting in a total of 239 studied cases, of which $37.2 \%$ $(89 / 239)$ were female and $62.8 \%(150 / 239)$ male.

Figures 1 and 2 show the age pyramids of cases and the Bauru population (IBGE. http:// www.ibge.gov.br/home/estatistica/populacao/ censo2010/caracteristicas_da_populacao/de fault_caracteristicas_da_populacao.shtm, accessed on 23/Jan/2011).

\section{Incidence rates and time series analysis}

Table 1 shows the number of annual cases and projected population and respective disease incidence. These results show an increase in AVL incidence during the period studied, with the greatest incidence occurring in 2006. The same trend can be observed in the time series decomposition chart shown below (Figure 3) that indicates a positive tendency over the analyzed period.

Figure 4 demonstrates the seasonal indexes obtained from the time series model and the average monthly rainfall between 2003 and 2008 . It shows that months with positive index values were preceded by rainy periods. From October through January there was a gradual increase of

Figure 1

Age pyramid of American visceral leishmaniasis (AVL) cases in Bauru, São Paulo State, Brazil, 2003-2008.

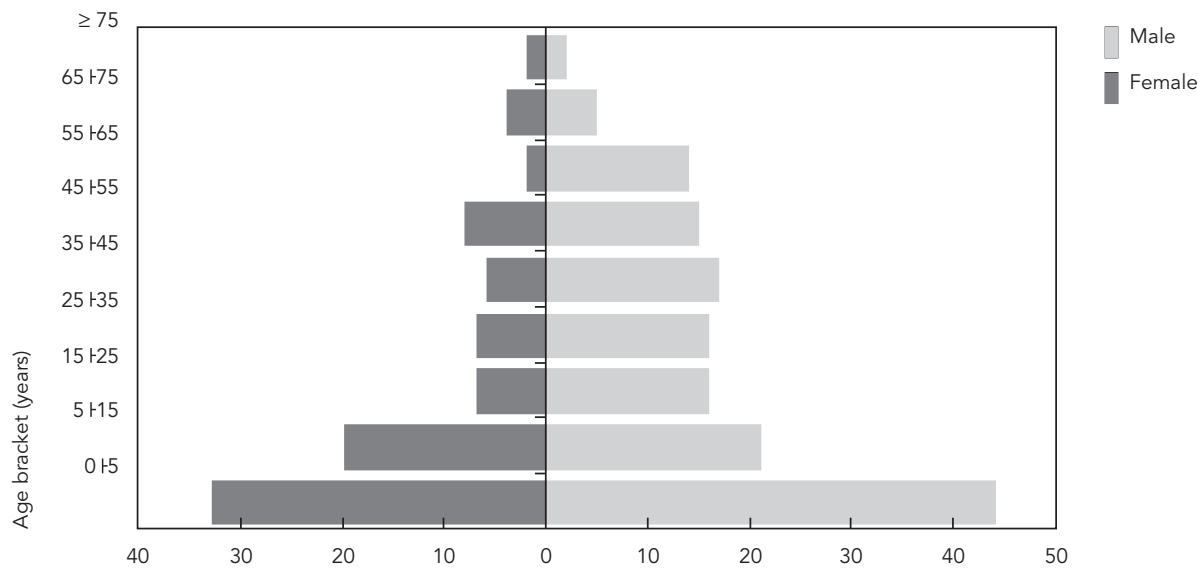




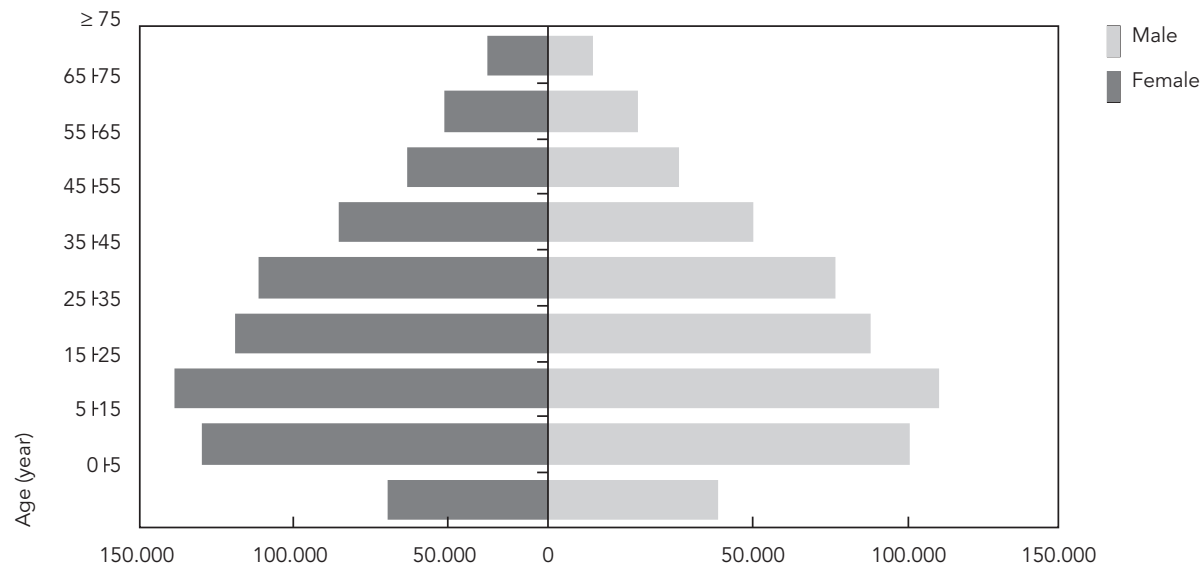

Table 1

Number of American visceral leishmaniasis (AVL) cases, projected population and AVL incidence rate in Bauru, State of São Paulo, Brazil, 2003-2008.

\begin{tabular}{lccc}
\hline Year & Cases & Projected population * & $\begin{array}{c}\text { Incidence (per 100,000 } \\
\text { inhabitants) }\end{array}$ \\
\hline 2003 & 16 & 331,806 & 4.82 \\
2004 & 29 & 337,492 & 8.59 \\
2005 & 34 & 343,148 & 9.91 \\
2006 & 68 & 347,747 & 19.55 \\
2007 & 39 & 352,409 & 11.07 \\
2008 & 53 & 357,132 & 14.84 \\
\hline
\end{tabular}

* Fundação Seade. http://www.seade.gov.br/produtos/perfil/perfil.php?loc=60 (accessed on 08/Aug/2011).

average precipitation leading to monthly seasonal indexes greater than 1 between November and February. A linear regression analysis was carried out to test for a possible correlation between the obtained seasonal indexes and mean rainfall in the respective previous month, which showed a low, but positive, result $\left(\mathrm{R}^{2}=0.35\right)$.

Although the relation between seasonal index and the respective previous month average temperature was also tested using linear regression analysis, no significant correlation was observed $\left(\mathrm{R}^{2} \approx 0.01\right)$. This can be explained by low temperature fluctuations during this period, which varied between 18 and $25^{\circ} \mathrm{C}$.

\section{Cluster analysis}

The space-time cluster analysis detected the concentration of the disease in 70 census tracts in 2006 in the southeast side of the city ( $p \leq 0.001)$, of which 38 presented 52 autochthonous human AVL cases. Two secondary clusters were identified, but neither of them was statistically significant ( $p \geq 0.05$ ). Figures 5 and 6 show the identified clusters. Annual cases of human AVL are shown in Figures 7, 8, 9, 10, 11, and 12, highlighting the spatial evolution of disease distribution. It should be noted that cases occurring at the same location (i.e., in the same block), are represented by a single point. 
Time series decomposition of Human American visceral leishmaniasis (AVL) cases in Bauru, São Paulo State, Brazil, $2003-2008$.
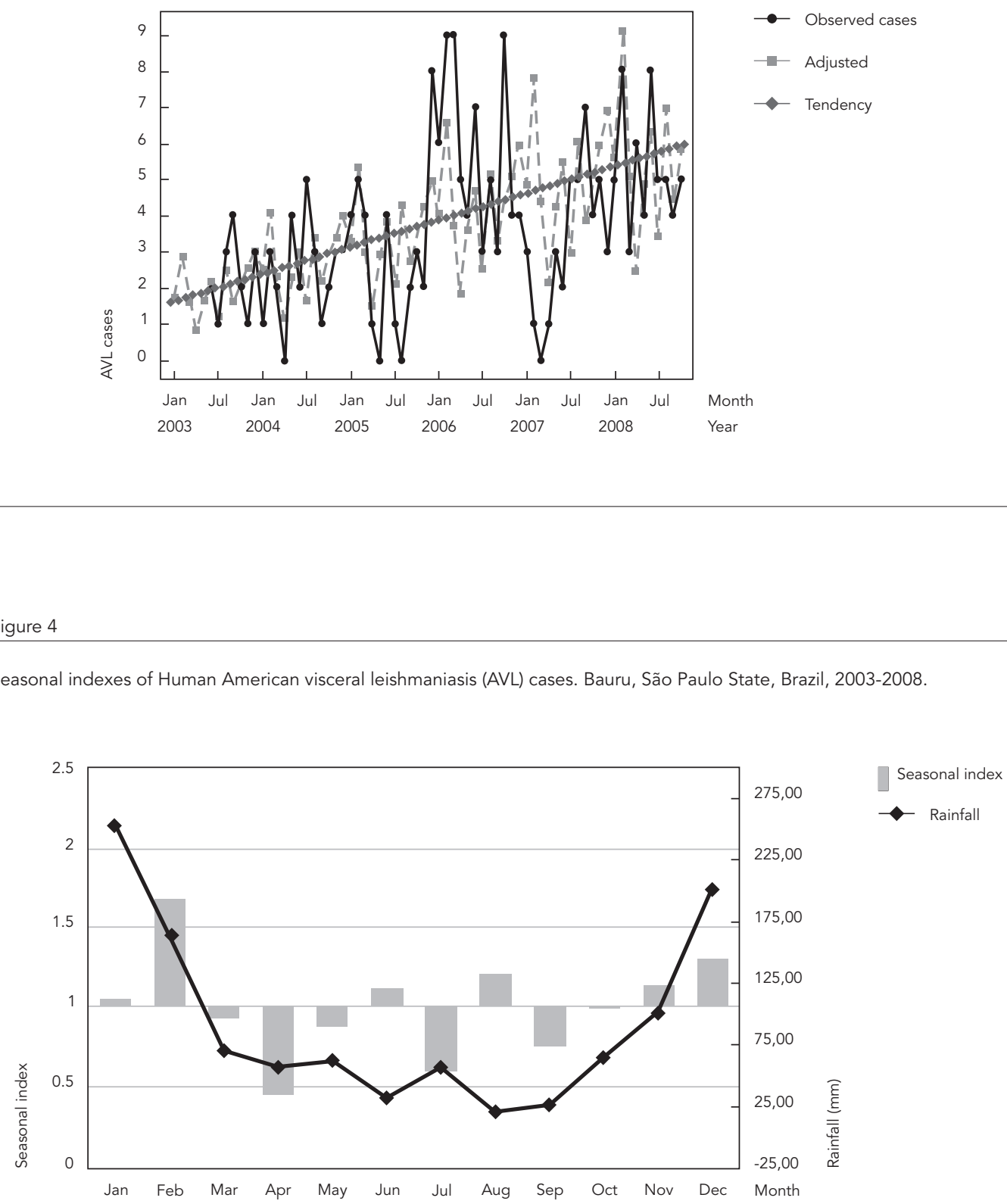

\section{Discussion}

Although AVL occurs worldwide, the most concentrated areas of the disease are located in developing countries (World Health Organization. http://www.who.int/leishmaniasis/en, accessed on 08/Aug/2011). In Brazil, the disease is considered endemic in several cities and diagnosed cases have been identified in the country's North, Northeast, Central West and Southeast regions.

Autochthonous AVL was first notified in Bauru in 2003 and, despite the implementation of recommended control and prevention measures, the disease continues to spread in this city.

Data on patients in Bauru showed that the disease was more common in males $(62.8 \%)$ than 
Figure 5

Space-time cluster of Human American visceral leishmaniasis (AVL) (2006) and distribution of cases in Bauru, São Paulo State, Brazil, $2003-2008$.

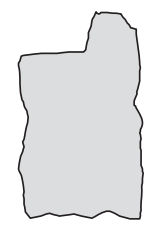

- Human AVL cases

Space-time cluster (2006)

Bauru urban area
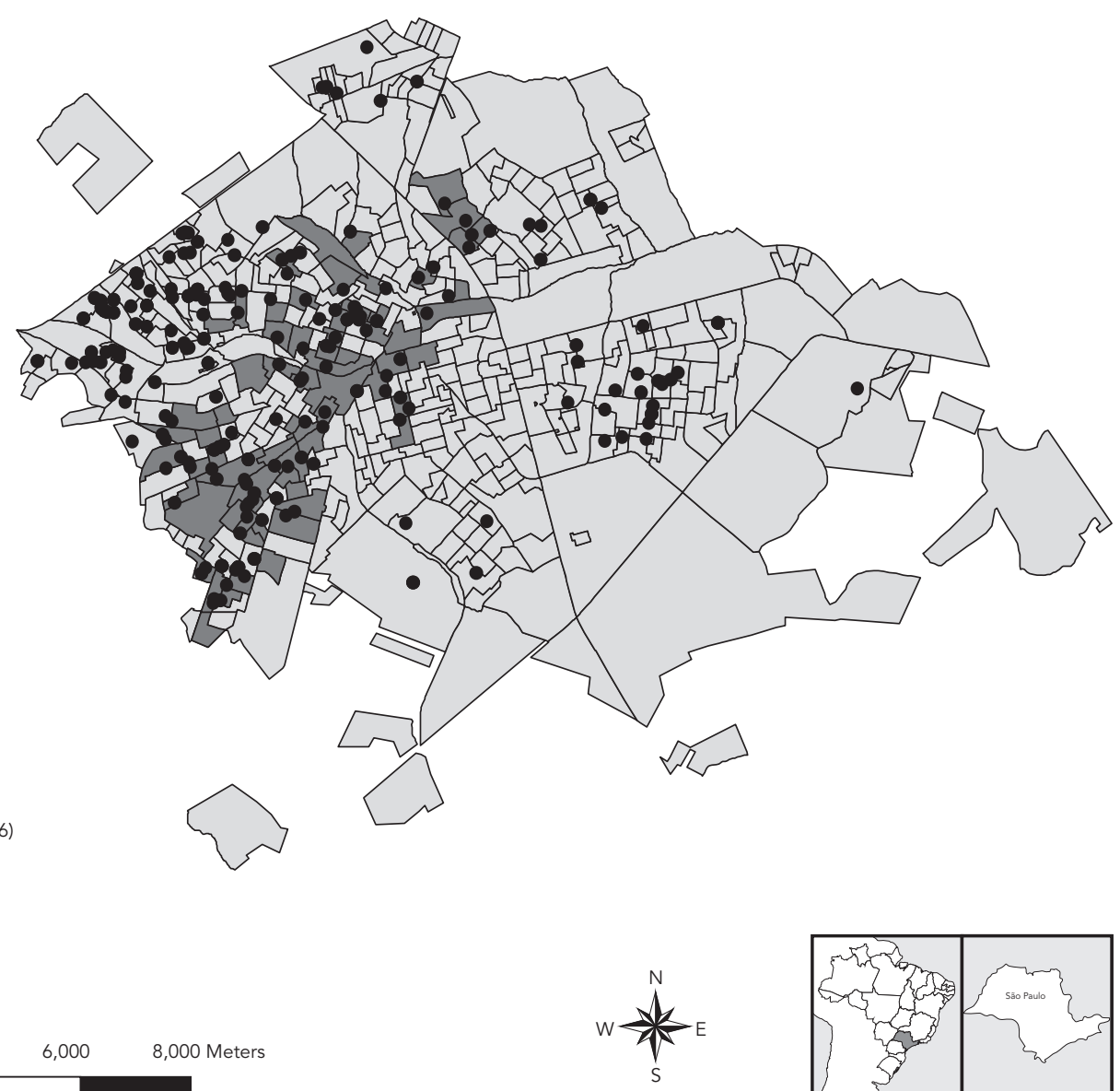


\section{Figure 6}

Secondary space-time clusters of Human American visceral leishmaniasis (AVL) $(p=0.936$ and $p=0.214)$. Bauru, São Paulo State, Brazil, $2003-2008$.

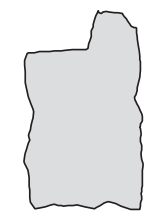

Space-time secondary cluster (2006)

Space-time secondary cluster (2006-2007) Bauru urban area
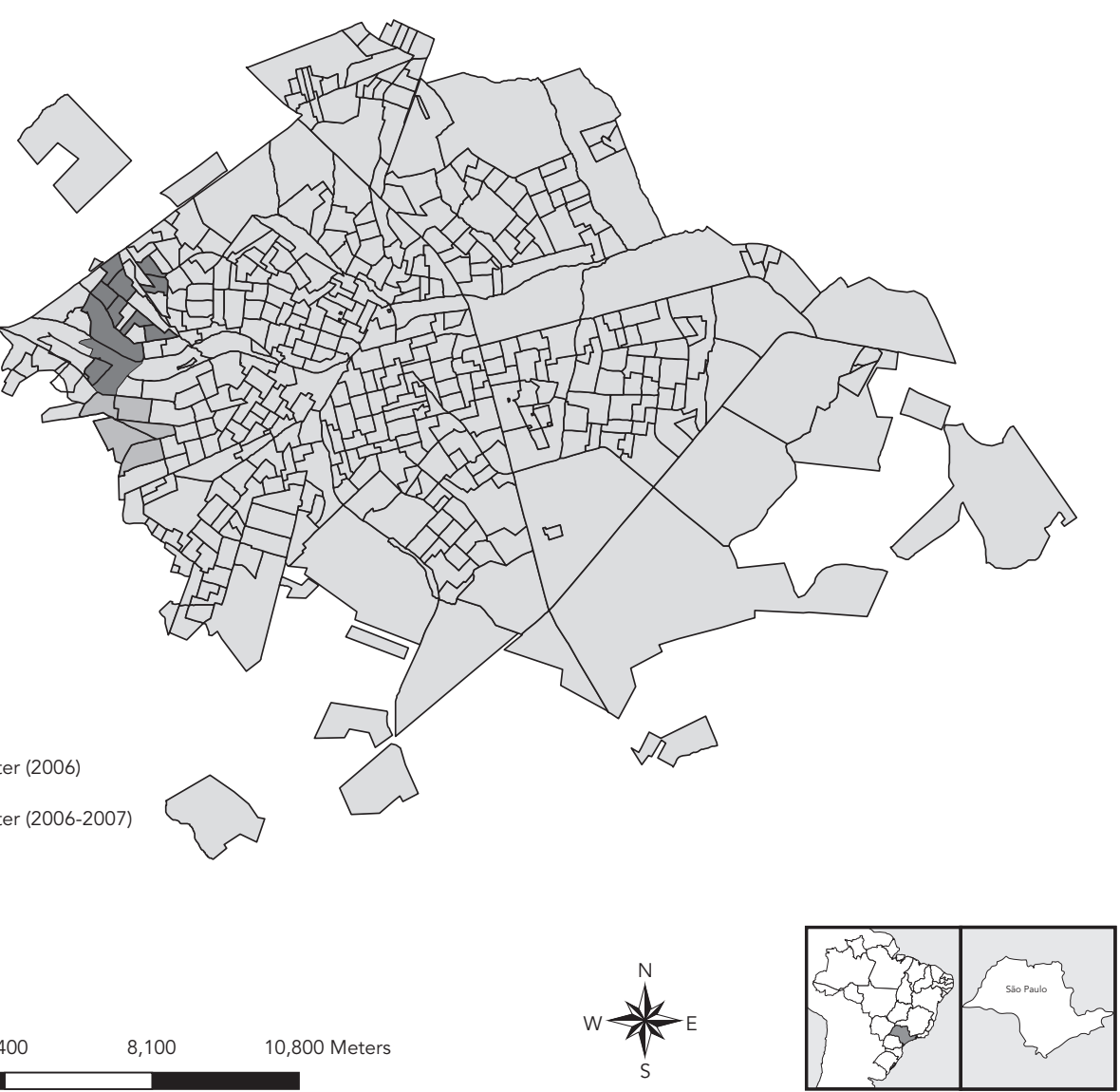
Figure 7

Human American visceral leishmaniasis (AVL) cases in Bauru, São Paulo State, Brazil, 2003.

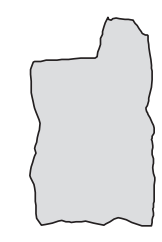

- Human AVL cases (2003)

Bauru urban area

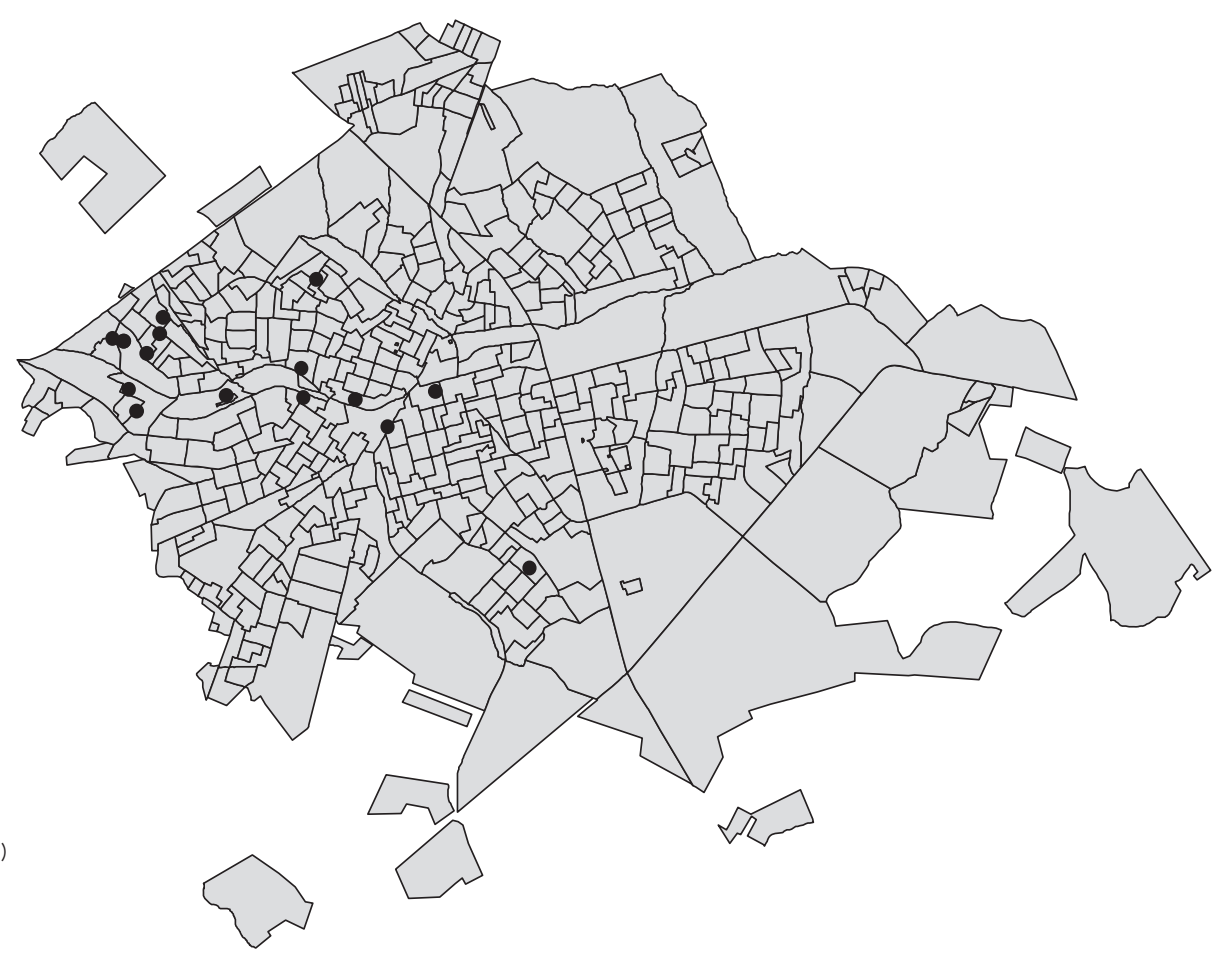

$\begin{array}{lll}0 & 1,350 \quad 2,700\end{array}$

8,100

10,800 Meters

$\left.w\right|_{s} ^{N}$

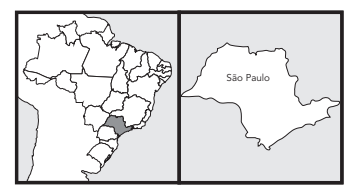


Figure 8

Human American visceral leishmaniasis (AVL) cases in Bauru, São Paulo State, Brazil, 2004

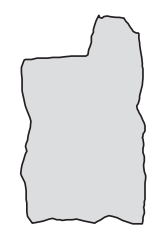

- Human AVL cases (2004)

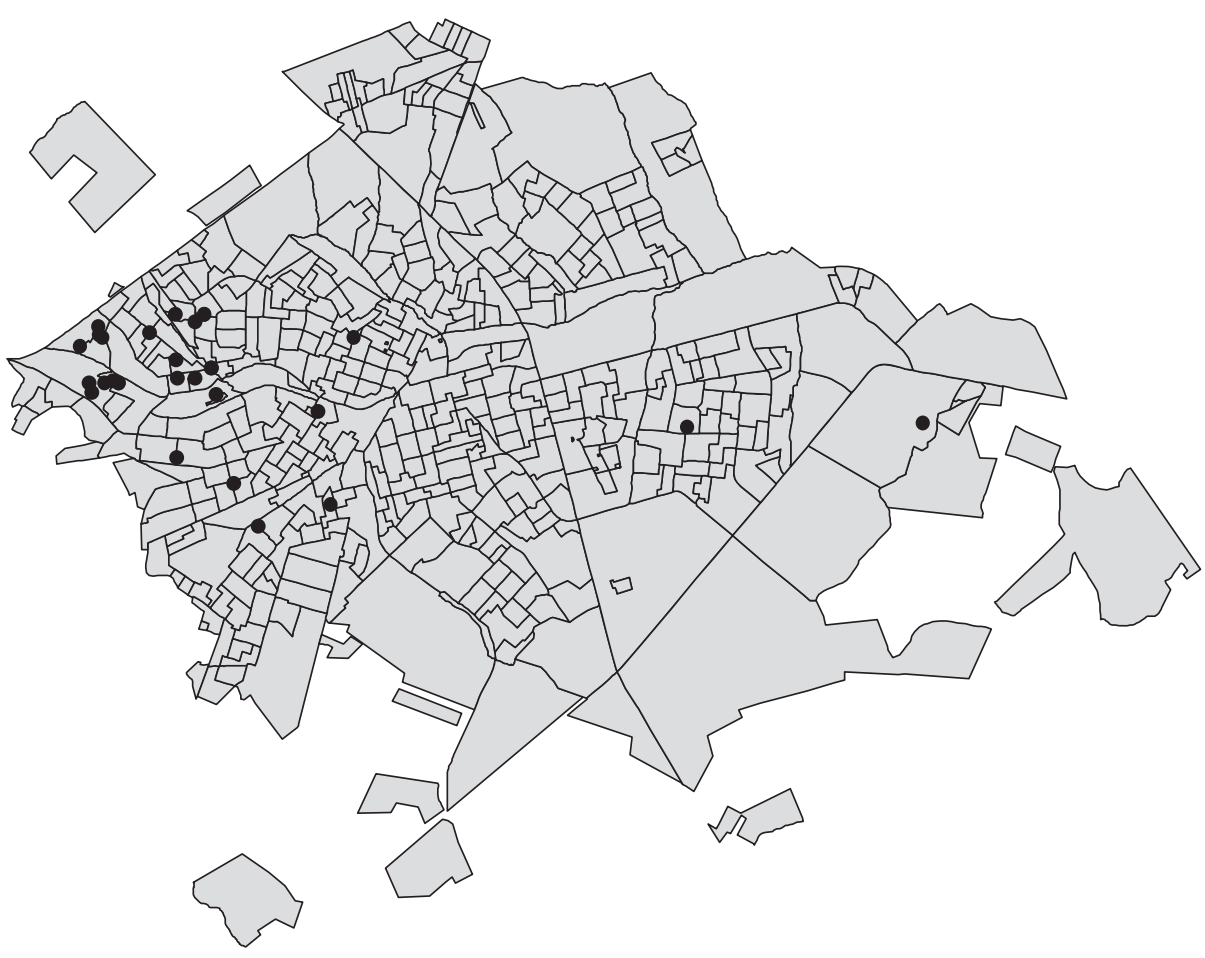

Bauru urban are
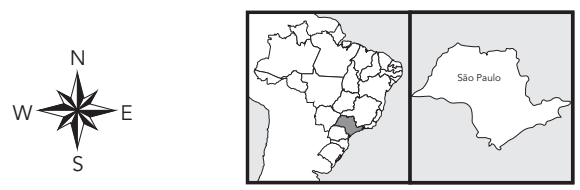
Figure 9

Human American visceral leishmaniasis (AVL) cases, Bauru, São Paulo State, Brazil, 2005
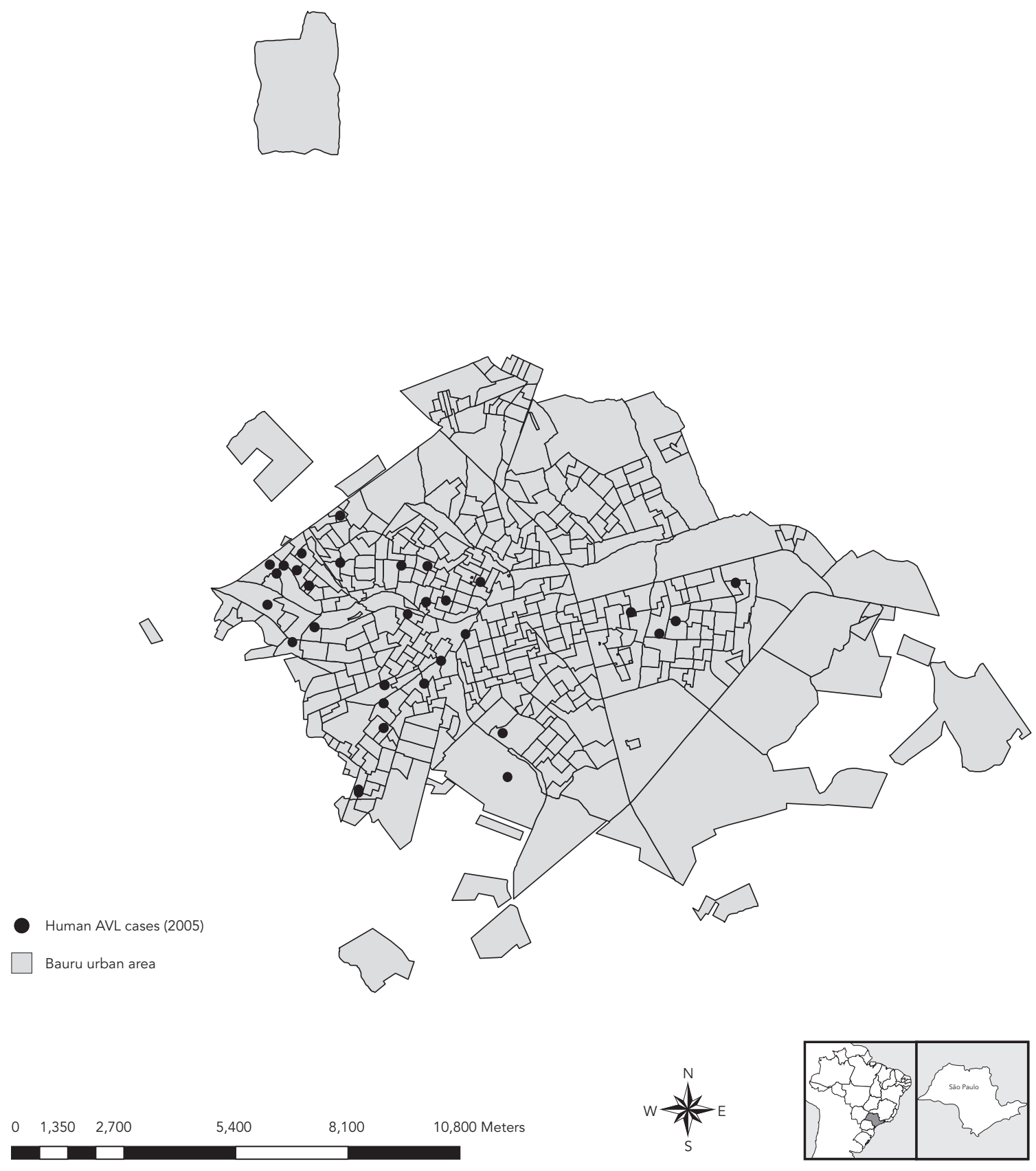
Figure 10

Human American visceral leishmaniasis (AVL) cases in Bauru, São Paulo State, Brazil, 2006

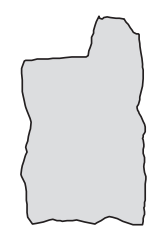

Human AVL cases (2006)

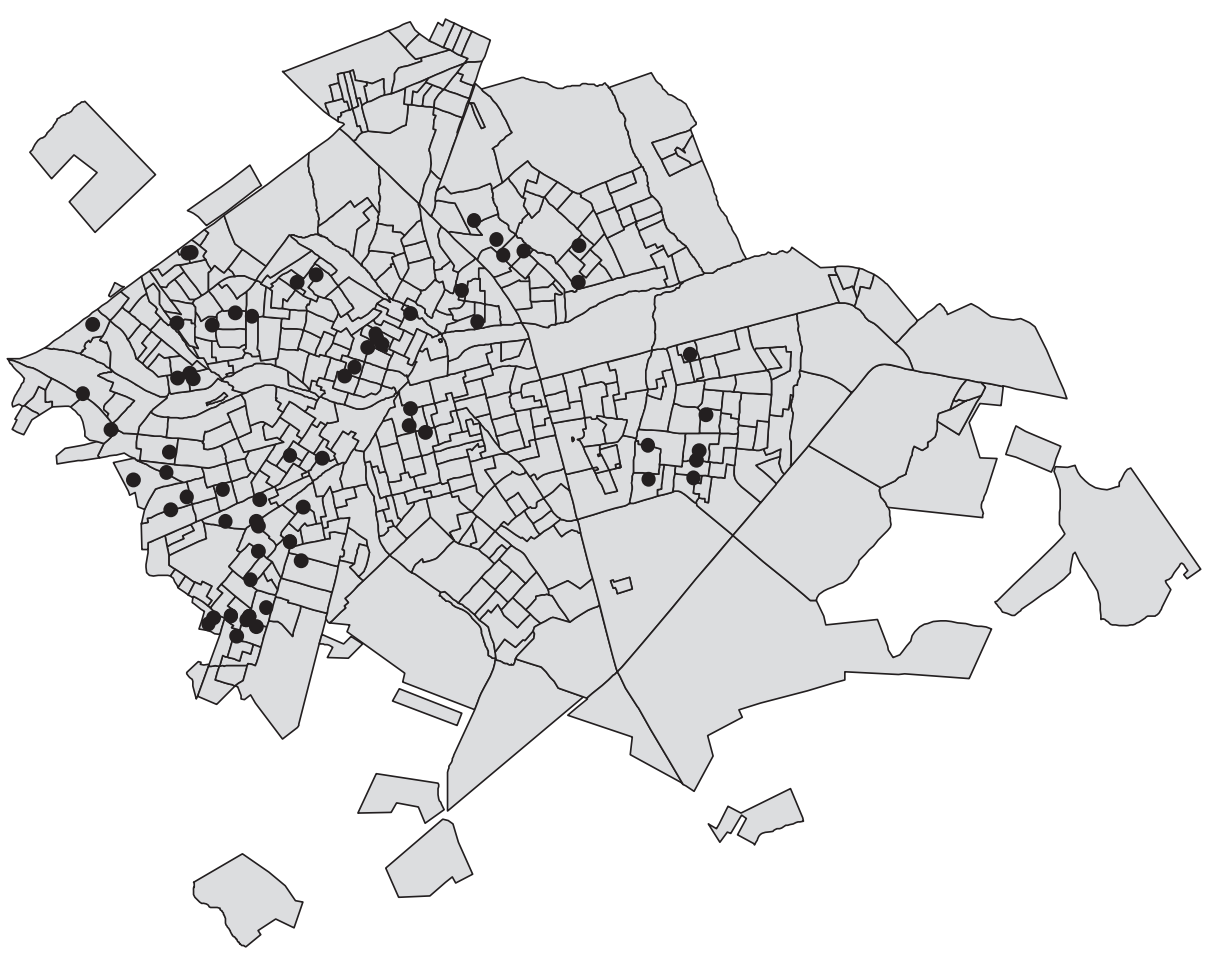

Bauru urban area
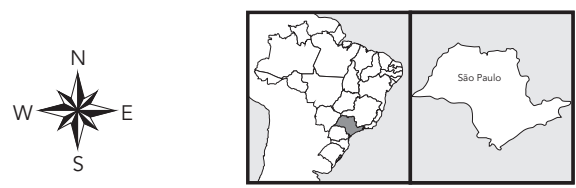
Figure 11

Human American visceral leishmaniasis (AVL) cases in Bauru, São Paulo State, Brazil, 2007

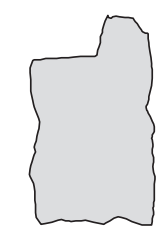

Human AVL cases (2007)

Bauru urban area

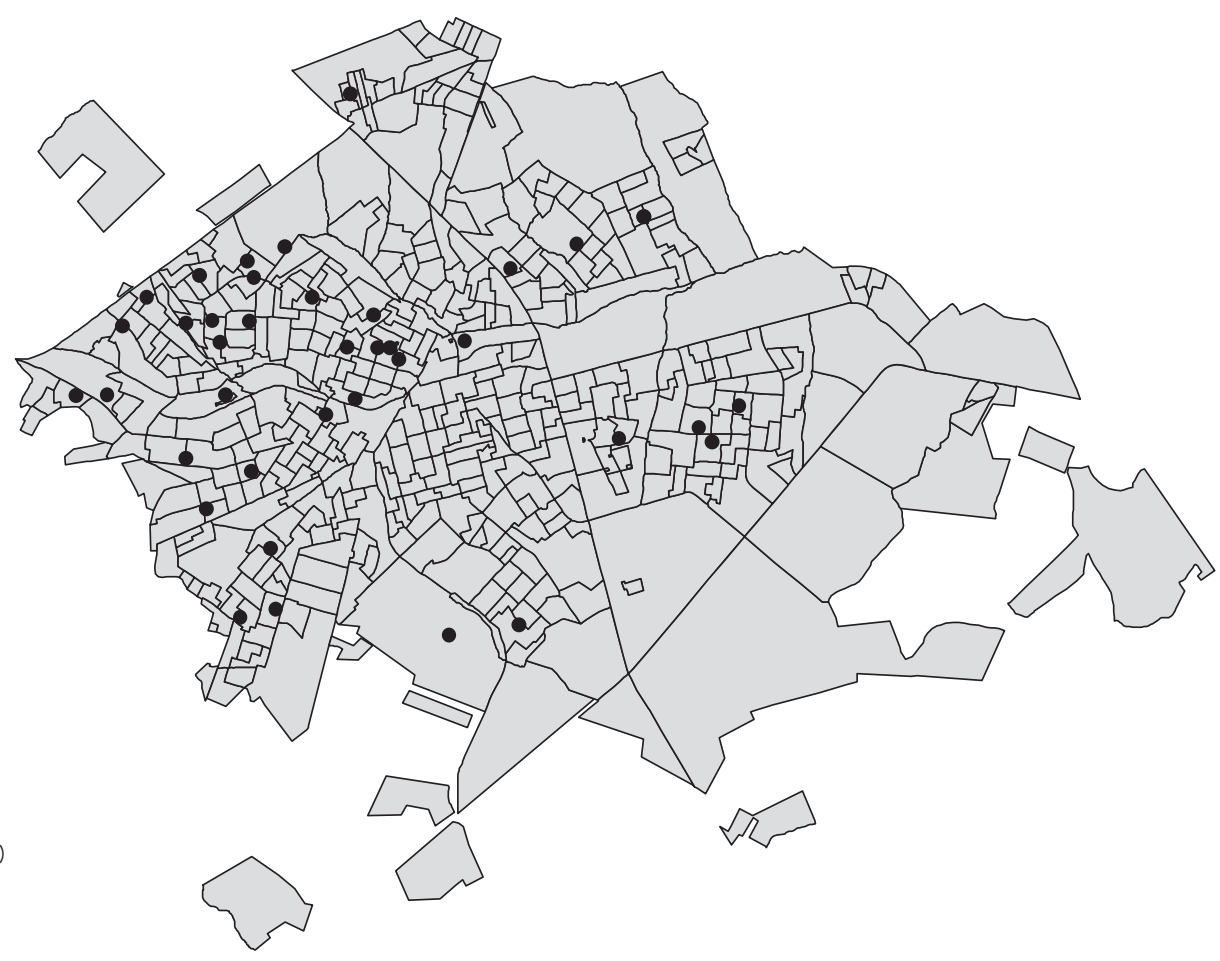

$0 \quad 1,350 \quad 2,700$ 
Figure 12

Human American visceral leishmaniasis (AVL) cases in Bauru, São Paulo State, Brazil, 2008.

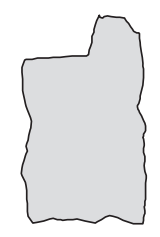

Human AVL cases (2008)

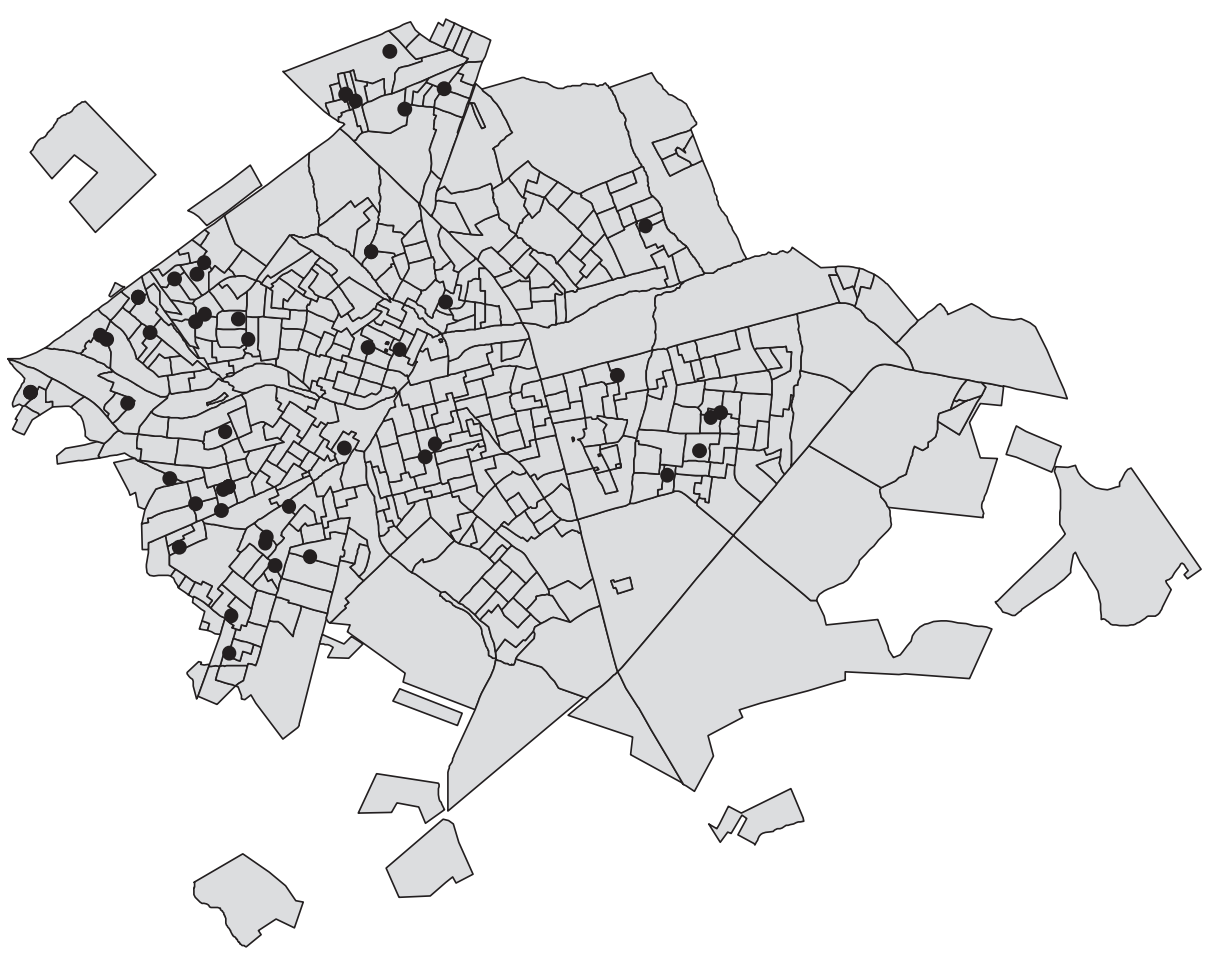

Bauru urban area
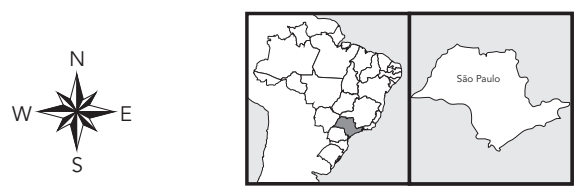
in females $(37.2 \%)$ and the most affected age groups were zero to four years (77/239) and five to 15 years $(41 / 239)$. This kind of profile has already been reported in Brazil 16 and other countries, including Uganda 13,14, Kenya 14, Ethiopia 15, Sudan 16, Nepal 16 and India 16. Despite being a common finding, the explanation for this trend remains uncertain. Factors that may explain this pattern include exposure, vulnerability and health-seeking behavior 16 .

Considering the period June 2003 to October 2008 , annual incidence rates per 100,000 inhabitants showed a clear increase in the disease, with the highest incidence occurring in 2006 (19.55).

This finding is confirmed by the time series analysis that identified a positive trend in the expansion of the disease over the study period. This analysis also determined the seasonal index that was low when compared to mean previous month rainfall.

Previous studies have shown a positive correlation between climatic variables, such as temperature, relative humidity and rainfall, and phlebotomine density $17,18,19,20$. Our findings corroborate these results, showing that vector count is related to human and canine AVL incidence 19,21.

Bauru is characterized by a constantly warm climate, with average temperatures over the analyzed period between $18^{\circ}$ and $25^{\circ} \mathrm{C}$, which may suggest why this variable did not influence the obtained seasonal index.

A similar result was noticed in a study realized in Porteirinha in the State of Minas Gerais, Brazil where no correlation between temperature and increases in density of sand flies was found, probably due to a lack of significant temperature fluctuations over the study period. According to the authors, rainfall index and relative humidity were decisive factors for the population dynamics of the phlebotomine sandfly in the region 22 .

The use of geographic information system (GIS) tools in epidemiologic studies has increased and improved over recent years, allowing a better understanding of disease distribution in both space and time.

Although spatial and space-time analysis using GIS and remote sensing have been the focus of several studies concerning leishmaniasis
$23,24,25,26,27,28,29$, few studies in Brazil have addressed AVL cluster analysis.

It was possible to detect whether the disease was homogeneously distributed throughout the city of Bauru between 2003 and 2008. In 2006, a cluster was localized in the Southeast and Central regions of the city. Despite high incidence in 2007 and 2008, AVL cases were spread throughout the city, explaining the absence of space-time cluster identification during these periods.

Unfortunately, data on the density of Lutzomyia longipalpis and the distribution of canine AVL cases, an important input for explaining the results obtained by this study, was unavailable.

The current study allowed us to verify that $\mathrm{AVL}$ is restricted almost exclusively to the Bauru urban area and disseminated throughout virtually the whole of this area, confirming previous research that emphasizes that this disease is associated with urbanization $30,31,32$. It was not possible to carry out a socioeconomic analysis due to lack of case information. Several studies in other areas have reported that socioeconomic variables, such as household structure, malnutrition and poverty are important risk factors for visceral leishmaniasis $33,34,35$ and we therefore suggest that further research should be carried in this field.

The possible participation of wild and synanthropic animals in the Leishmania spp. cycle should also be noted. Santiago et al. 36 tested samples of sera collected from opossums captured in urban and periurban areas in the city of Bauru for cutaneous and visceral leishmaniasis to test the hypothesis that this species could have influenced the occurrence of AVL in the region. The authors reported that the migration of opossums to urban areas has been happening since 1999, before the detection of canine AVL at the city 36 .

Our study allows us to conclude that, up until now, human AVL has been clustered in Bauru, and that the Southeast area of the city may require special attention regarding the implementation of control and prevention measures. These findings are a first approach and complementary research is necessary to confirm and obtain a better understanding of our results. 


\section{Resumo}

Uma análise espaço-temporal da leishmaniose visceral americana (LVA) em Bauru, São Paulo, Brasil, foi realizada com base em 239 casos diagnosticados entre junho de 2003 e outubro de 2008. A análise espacial da doença demonstrou que os casos ocorreram especialmente na área urbana da cidade. A incidência anual de LVA foi calculada, demonstrando que a taxa mais elevada foi verificada em 2006 (19,55/100 mil habitantes). O fato foi confirmado pela análise da série histórica, que também apresentou uma tendência positiva durante o período analisado. O presente estudo permitiu concluir que a doença esteve aglomerada na região sudoeste de Bauru no ano de 2006, e que tal área pode exigir atenção especial com relação às medidas de controle e prevenção.

Leishmaniose Visceral; Análise por Conglomerados; Análise Espacial

\section{Contributors}

V. A. F. Souza contributed to study design, data analysis and interpretation, writing of this manuscript, and approved the final version of this article. L. R. P. B. Cortez contributed to study design, data acquisition, critical review of the intellectual content, and approved the final version of this article. R. A. Dias, M. Amaku, J. S. Ferreira Neto and R. B. S. Kuroda contributed to data analysis and interpretation and the critical review of the intellectual content, and approved the final version of this article. F. Ferreira contributed to study design, data analysis and interpretation and critical review of the intellectual content, and approved the final version of this article.

\section{Acknowledgments}

The authors wish to thank FAPESP for their financial support (grant number 2009/04074-3) and Capes.

\section{References}

1. Laison R, Shaw JJ. Microbiology and microbial infections. London: Hodder Arnold; 2005.

2. Coutinho SG, Nunes MP, Marzoch MCA, Tramontano NA. Surgery for American cuteneous and visceral leishmaniasis among 1,342 dogs from areas in Rio de Janeiro (Brazil) where the human diseases occur. Mem Inst Oswaldo Cruz 1985; 80:17-22.

3. Courtenay O, Quinnell RJ, Garcez LM, Shaw JJ, Dye C. Infectiousness in a cohort of Brazilian dogs: why culling fails to control visceral leishmaniasis in areas of high transmission. J Infect Dis 2002; 186:1314-20.

4. Pearson RD, Sousa ADQ. Clinical spectrum of leishmaniasis. Clin Infect Dis 1996; 22:1-11.

5. Centro de Vigilância Epidemiológica "Prof. Alexandre Vranjac", Coordenadoria de Controle de Doenças, Secretaria do Estado da Saúde de São Paulo. Manual de vigilância e controle da leishmaniose visceral americana do Estado de São Paulo. São Paulo: Secretaria do Estado da Saúde de São Paulo; 2006.
6. Centro de Vigilância Epidemiológica "Prof. Alexandre Vranjac", Coordenadoria de Controle de Doenças, Secretaria do Estado da Saúde de São Paulo. Atualização da classificação epidemiológica dos municípios para a leishmaniose visceral americana. Estado de São Paulo, agosto de 2008. Boletim Epidemiológico Paulista 2008; 5:22-5.

7. Centro de Vigilância Epidemiológica "Prof. Alexandre Vranjac", Coordenadoria de Controle de Doenças, Secretaria do Estado da Saúde de São Paulo. Casos autóctones e óbitos de LVA, no Estado de São Paulo, 1999 a 2011. http://www.cve. saude.sp.gov.br/htm/zoo/lvah (accessed on 08/ Aug/2011).

8. Departamento de Vigilância Epidemiológica, Secretaria de Vigilância em Saúde, Ministério da Saúde. Manual de vigilância e controle da leishmaniose visceral. Brasília: Ministério da Saúde; 2003.

9. Marshall RJ. A review of methods for the statistical analysis of spatial patterns of disease. J R Stat Soc Ser A Stat Soc 1991; 154:421-41. 
10. Carvalho MS, Souza-Santos, R. Análise de dados espaciais em saúde pública: métodos, problemas, perspectivas. Cad Saúde Pública 2005; 21:361-78.

11. Werneck GL, Struchiner CJ. Estudos de agregados de doença no espaço-tempo: conceitos, técnicas e desafios. Cad Saúde Pública 1997; 13:611-24.

12. Kulldorff M. SaTScan users guide for version 8.0. http://www.satscan.org (accessed on 10/ Jun/2010).

13. Mueller Y, Mbulamberi DB, Odermatt P, Hoffmann A, Loutan L, Chappuis F. Risk factors for in-hospital mortality of visceral leishmaniasis patients in eastern Uganda. Trop Med Int Health 2009; 14:910-7.

14. Kolaczinski JH, Reithinger R, Worku DT, Ocheng A, Kasimiro J, Kabatereine N, et al. Risk factors of visceral leishmaniasis in East Africa: a case-control study in Pokot territory of Kenya and Uganda. Int J Epidemiol 2008; 37:344-52.

15. Alvar J, Bashaye S, Argaw D, Cruz I, Aparicio P, Kassa A, et al. Kala-azar outbreak in Libo Kemkem, Ethiopia: epidemiologic and parasitologic assessment. Am J Trop Med Hyg 2007; 77:275-82.

16. Harhay MO, Olliaro PL, Vaillant M, Chappuis F, Lima MA, Ritmeijer K, et al. Who is a typical patient with visceral leishmaniasis? Characterizing the demographic and nutritional profile of patients in Brazil, East Africa, and South Asia. Am J Trop Med Hyg 2011; 84:543-50.

17. Deane LM, Deane MP. Visceral leishmaniasis in Brazil: geographical distribution and transmission. Rev Inst Med Trop São Paulo 1962; 4:198-212.

18. Rebêlo JMM. Freqüência horária e sazonalidade de Lutzomyia longipalpis (Diptera: Psychodidae: Phlebotominae) na Ilha de São Luís, Maranhão, Brasil. Cad Saúde Pública 2001; 17:221-7.

19. Resende MC, Camargo MC, Vieira JR, Nobi RC, Porto MN, Oliveira CD, et al. Seasonal variation of Lutzomyia longipalpis in Belo Horizonte, State of Minas Gerais. Rev Soc Bras Med Trop 2006; 39:51-5.

20. Oliveira AG, Galati EA, Fernandes CE, Dorval ME, Brazil RP. Seasonal variation of Lutzomyia longipalpis (Lutz \& Neiva, 1912) (Diptera: Psychodidae: Phlebotominae) in endemic area of visceral leishmaniasis, Campo Grande, state of Mato Grosso do Sul, Brazil. Acta Trop 2008; 105:55-61.

21. Ximenes MFFM, Castello EG, Souza MFD, Menezes AAL, Queiroz JW, Silva VPME, et al. Effect of abiotic factors on seasonal population dynamics of Lutzomyia longipalpis (Diptera: Psychodidae) in Northeastern Brazil. J Med Entomol 2006; 43:990-5.

22. Barata RA, Silva JCFD, Costa RTD, Fortes-Dias CL, Silva JCD, Paula, EVD, et al. Phlebotomine sand flies in Porteirinha, an area of American visceral leishmaniasis transmission in the State of Minas Gerais, Brazil. Mem Inst Oswaldo Cruz 2004; 99:481-7.

23. Camargo-Neves VL, Katz G, Rodas LA, Poletto DW, Lage LC, Spinola RM, et al. Use of spatial analysis tools in the epidemiological surveillance of American visceral leishmaniasis, Araçatuba, São Paulo, Brazil, 1998-1999. Cad Saúde Pública 2001; 17:1263-7.
24. Oliveira CD, Assuncao RM, Reis IA, Proietti FA. Spatial distribution of human and canine visceral leishmaniasis in Belo Horizonte, Minas Gerais State, Brasil, 1994-1997. Cad Saúde Pública 2001; 17:1231-9.

25. Werneck GL, Costa CH, Walker AM, David JR, Wand M, Maguire JH. The urban spread of visceral leishmaniasis: clues from spatial analysis. Epidemiology 2002; 13:364-7.

26. Werneck GL, Maguire JH. Spatial modeling using mixed models: an ecologic study of visceral leishmaniasis in Teresina, Piauí State, Brazil. Cad Saúde Pública 2002; 18:633-7.

27. Ryan JR, Mbui J, Rashid JR, Wasunna MK, Kirigi G, Magiri C, et al. Spatial clustering and epidemiological aspects of visceral leishmaniasis in two endemic villages, Baringo District, Kenya. Am J Trop Med Hyg 2006; 74:308-17.

28. Salah AB, Kamarianakis Y, Chlif S, Alaya NB, Prasta$\cos$ P. Zoonotic cutaneous leishmaniasis in central Tunisia: spatio-temporal dynamics. Int J Epidemiol 2007; 36:991-1000.

29. Ben-Ahmed K, Aoun K, Jeddi F, Ghrab J, El-Aroui MA, Bouratbine A. Visceral leishmaniasis in Tunisia: spatial distribution and association with climatic factors. Am J Trop Med Hyg 2009; 81:40-5.

30. Oliveira AGD, Galati EAB, Oliveira OD, Oliveira GRD, Espindola IAC, Dorval MEC, et al. Abundance of Lutzomyia longipalpis (Diptera: Psychodidae: Phlebotominae) and urban transmission of visceral leishmaniasis in Campo Grande, state of Mato Grosso do Sul, Brazil. Mem Inst Oswaldo Cruz 2006; 101:869-74.

31. Costa CHN. Characterization and speculations on the urbanization of visceral leishmaniasis in Brazil. Cad Saúde Pública 2008; 24:2959-63.

32. Rangel EF, Vilela ML. Lutzomyia longipalpis (Diptera, Psychodidae, Phlebotominae) and urbanization of visceral leishmaniasis in Brazil. Cad Saúde Pública 2008; 24:2948-52.

33. Costa CH, Werneck GL, Rodrigues Jr. L, Santos MV, Araújo IB, Moura LS, et al. Household structure and urban services: neglected targets in the control of visceral leishmaniasis. Ann Trop Med Parasitol 2005; 99:229-36.

34. Alvar J, Yactayo S, Bern C. Leishmaniasis and poverty. Trends Parasitol 2006; 22:552-7.

35. Kolaczinski JH, Reithinger R, Worku DT, Ocheng A, Kasimiro J, Kabatereine N, et al. Risk factors of visceral leishmaniasis in East Africa: a case-control study in Pokot territory of Kenya and Uganda. Int J Epidemiol 2008; 37:344-52.

36. Santiago ME, Vasconcelos RO, Fattori KR, Munari DP, Michelin AF, Lima VM. An investigation of Leishmania spp. in Didelphis spp. from urban and peri-urban areas in Bauru (Sao Paulo, Brazil). Vet Parasitol 2007; 150:283-90.

Submitted on $28 /$ Sep/2011

Final version resubmitted on 03/Jun/2012 Approved on 02/Jul/2012 